\title{
ANALISIS FAKTOR-FAKTOR YANG BERPENGARUH TERHADAP TINGKAT KEBERHASILAN PADA PERUSAHAAN-PERUSAHAAN DAGANG DI KOTAMADYA BANJARMASIN \\ Oleh: H. M. Rudiansyah
}

\begin{abstract}
This research is aimed to analize to factors that success of business. The factors analize in the research are; $X_{1}$ (net selling), $X_{2}$ (cost expense), $X_{3}$ (working capital), $X_{4}$ (gross profit), $X_{5}$ (profit margin), $X_{6}$ (total assets), dan $X_{7}$ (turnover assets). The analysis tool that is used in the research is the multiple linier regression model, regression equations that show the variables $X_{1}, X_{2}, X_{3}, X_{4}, X_{5}, X_{6}$ simultaneously give sinigficant afferst to variable $Y$. This is show in the test $F$ result calculation $(2,897)$ is higher than the table $F(2,17)$, and its probability value (1.778E-9) is lower the value of alfa $(\alpha=0,05)$ While the dominant factor that affects sucsess of business is the profit margin $\left(X_{5}\right)$.
\end{abstract}

Key words; net selling, cost expense, working capita), gross profit, profit margin, total assets, turnover assets.

\section{PENDAHULUAN}

Dalam kondisi perkonomian yang semakin kompleks dan kondisi persaingan yang semakin ketat, serta kemampuan daya beli masyarakat terbatas, diperlukan kemampuan manajerial yang semakin tinggi dan pengelolaan sumber daya perusahaan yang maksimal.

Secara umum tujuan suatu perusahaan adalah memaksimalisasi laba, suatu usaha dikatakan berhasil apabila mampu menjalankan aktivitasnya sesuai dengan harapan-harapan atas pengoperasian usaha tersebut. Untuk mengetahui lebih lanjut tentang prestasi-prestasi dari perusahaan tidak hanya melihat saja, tetapi lebih jauh harus melakukan analisis, apakah usaha tersebut mempunyai prestasi keuangan yang lebih baik. Analisis dan interpretasi ratio keuangan dapat memberikan gambaran tentang kondisi dan prestasi perusahaan

Kondisi keuangan dari suatu perusahaan dapat diketahui dengan suatu tolok ukur yang biasa dipakai yaitu ratio keuangan dan angka artio-ratio keuangan tersebut selanjutnya diinterpretasikan. Menurut Van Horn (2009) mengemukakan: "To evaluate the financial condition and performance of a firm, the financial analyst needs certain yardstick. The yardstick frequently used is a ratio, or index relating two pieces of financial data to each other. Analysis and interpretatition of varios ratios should give experienced, skilled analysis a better under standing of financial condition and performance of the firm then they would obtain from analysis of the financial data alone" 
Satu diantara ukuran yang dapat menggambarkan keberhasilan atau efisiensi suatu perusahaan dalam menggunakan aktivanya atau modalnya secara produktif adalah rentabilitas. Menurut Bambang Riyanto (2010) menyebutkan bahwa rentabilitas didefinisikan sebagai perbandingan antara laba usaha dengan modal sendiri dan modal asing yang dipergunakan untuk menghasilkan laba tersebut dan dinyatakan dalam persentase. S. Munawir (2010) menyatakan bahwa rentabilitas (profitability) adalah kemampuan perusahaan untuk menghasilkan laba selama periode tertentu.

Rentabilitas sering juga disebut earning power yang dimaksudkan sebagai kemampuan perusahaan dengan seluruh modal yang bekerja di dalamnya untuk menghasilkan laba. Perusahaan tidak hanya memperhatikan bagaimana usaha mempertinggi laba, tetapi yang lebih penting adalah bagaimana usaha mempertinggi rentabilitasnya, untuk mempertinggi rentabilitas perlu diketahui faktor-faktor yang mempengaruhi besar kecilnya rentabilitas (earning power).

Lebih jauh Bambang Riyanto (2010) menyebutkan bahwa hubungan antara beberapa faktor yang mempengaruhi besarnya earning power adalah profit margin dan turnover of capital assets. Kedua faktor tersebut pada dasarnya bermula pada besarnya penjualan bersih, biaya usaha, modal kerja (aktiva lancar), dan aktiva tetap.

Dengan demikian maka masalah yang dianalisis dalam penelitian ini adalah faktor yang diidentifikasi mempengaruhi rentabilitas (earning power), yaitu apakah faktor penjualan bersih, biaya usaha, modal kerja, laba usaha, profit margin, jumlah aktiva usaha dan perputaran aktiva mempunyai pengaruh terhadap rentabilitas, serta faktor manakah yang dominan pengaruhnya.

Berdasarkan rumusan masalah, tinjauan pustaka dan kerangka pendekatan, maka dapat dikemukakan hipotesis sebagai jawaban sementara dari permasalahan penelitian, yang selanjutnya diuji kebenarannya, yaitu bahwa faktor penjualan bersih, biaya usaha, modal kerja, laba usaha, profit margin, jumlah aktiva, dan perputaran aktiva mempunyai pengaruh terhadap rentabilitas (earning power), dan faktor penjualan bersih yang dominan berpengaruh terhadap rentabilitas pada perusahaan-perusahaan dagang di kotamadya Banjarmasin.

\section{METODE PENELITIAN}

\section{Identifikasi Variabel;}

Berdasarkan permasalahan dan kerangka pendekatan serta hipotesis yang diajukan, maka variabel yang dianalisis terdiri dari; pertama variabel tergantung (dependent Jumnal Riset Inspirasi Mangjemon dan Kewirausabaan 
variable) yaitu rentabilitas (earning power) yang disebut variabel $\mathrm{Y}$, kedua variabel bebas (independent variable) yaitu faktorfaktor yang mempengaruhi rentabilitas (earning power), yang selanjutnya disebut variabel $\mathrm{X}$ (yang teridiri dari variabel $\mathrm{X}_{1}$ penjualan bersih, $X_{2}$ biaya usaha, $X_{3}$ modal kerja, $\mathrm{X}_{4}$ laba usaha, $\mathrm{X}_{5}$ profit margin, $\mathrm{X}_{6}$ aktiva usaha, dan $\mathrm{X}_{7}$ perputaran aktiva.

\section{Jenis dan Suber Data;}

Jenis data yang dikumpulkan dalam penelitian ini adalah data kualitatif dan data kuantitatif yang bersumber dari data skunder, yang diperoleh dari perusahaan dagang dan instansi yang terkait, yang meliputi data perusahaan dan data laporan keuangan.

\section{Populasi dan Sampel;}

Jumlah populasi adalah jumlah perusahaan dagang yang mempunyai SIUP sebanyak 129 perusahaan, sedangkan sampel yang diambil dipilih berdasarkan kriteria tertentu yaitu dengan menggunakan purposive sampling atau judgement sample (Masri Singarimbun dan Sofyan Effendi, 2004) menyatakan bahwa pengambilan sampel yang bersifat tidak acak di mana sampel dipilih berdasarkan pertimbangan tertentu. Berdasarkan pertimbangan tertentu maka sampel dipilih sebanyak 60 perusahaan yang memenuhi persyaratan, yaitu bahwa usaha dagang merupakan kegiatan utama, dan usaha yang dilakukan sudah berjalan lima tahun.

\section{Teknik Analisis;}

Berdasarkan permasalahan dan hipotesis yang diajukan, digunakan alat analisis keuangan dengan alat teknis analisis statistika dengan menggunakan analisis regresi berganda yang didasarkan poling data, dengan model analisis;

$Y=b_{0}+b_{1} X_{1}+b_{2} X_{2}+b_{3} X_{3}+b_{4} X_{4}+$ $b_{5} X_{5}+b_{6} X_{6}+b_{7} X_{7}+e_{i}$

Dimana;

$\mathrm{Y}=$ rentabilitas (earning power)

$\mathrm{X}_{1}=$ penjualan bersih

$\mathrm{X}_{2}=$ biaya usaha

$\mathrm{X}_{3}=$ modal kerja

$\mathrm{X}_{4}=$ laba usaha

$\mathrm{X}_{5}=$ profit margin

$\mathrm{X}_{6}=$ aktiva usaha

$\mathrm{X}_{7}=$ perputaran aktiva

$\mathrm{b}_{0}=$ konstanta

$\mathrm{b}_{1} \ldots 7=$ koefisien regresi,

$\mathrm{e}_{\mathrm{i}}=$ variabel gangguan

Penggunaan model regresi tersebut, haruslah memenuhi asumsi-asumsi klasik yang mendasari model regresi, yang dalam ekonometri dinamakan Best Linier Unbiased Estimator/BLUE. (Djoko Mursinto, 2000)

\section{Pembuktian hipotesis;}

Untuk membuktikan hipotesis pertama dihitung koefisien korelasi multiplenya dengan rumus (Sudjana, 2003), yaitu: 
$\mathrm{R}=\sqrt{ }(\mathrm{JK} \cdot \mathrm{reg}) / \Sigma \mathrm{Y}^{2}$

Untuk membuktikan apakah koefisien korelasi multiplenya signifikan atau tidak dilakukan dengan uji $\mathrm{F}$, dengan rumus;

$\mathrm{F}=\left(\mathrm{R}^{2} / \mathrm{k}\right) /\left[\left(1-\mathrm{R}^{2}\right) /(\mathrm{n}-\mathrm{k}-1)\right]$

Hipotesis diterima bila $\mathrm{F}$ hitung lebih besar dari $\mathrm{F}$ tabel atau diperoleh harga $\mathrm{p}<$ 0,05. Sedangkan hipotesis kedua masingmasing koefisien regresinya diuji dengan menggunakan uji t, ( Sudjana, 1983);

$$
\mathrm{t}=\left[\mathrm{r}_{\mathrm{yi}} 12 . .(\mathrm{i}-1)(\mathrm{i}+1) \ldots \mathrm{k} \text { V } \mathrm{n}-\mathrm{k}-1\right] /
$$

$\left[\sqrt{ } 1-\mathrm{r}_{\mathrm{yi}} 12 . .(\mathrm{i}-1)(\mathrm{i}+1) . . \mathrm{k}\right]$

Hasil uji t bermakna bila diperoleh t hitung lebih besar dari t tabel atau diperoleh harga $\mathrm{p}<0,05$, pengaruh yang dominan ditentukan oleh harga $\mathrm{p}$ yang terkecil atau $\mathrm{r}^{2}$ partial yang terbesar.

\section{HASIL PENELITIAN}

Hasil penelitian yang diperoleh menunjukan bahwa keberhasilan perusahaan dagang yang digambarkan melalui rentabilitas (earning power) yang dipengaruhi oleh beberapa faktor sebagai berikut:

Variabel $\mathrm{X}_{1}$ penjualan bersih dari perusahaan dagang yang menjadi sampel penelitian menunjukan bahwa sebanyak 37 buah atau $56,67 \%$ melakukan penjualan sebanyak antara 50 juta rupiah sampai 350 juta rupiah setahun dan ini masih di bawah rata-rata penjualan dari kisaran antara 350 juta rupiah sampai dengan 450 juta rupiah, yang sama dengan rata-rata penjualan dari jumlah sampel sebanyak 3 buah perusahaan atau 5\%, dan sisanya sudah melebihi jumlah rata-rata yaitu sebanyak 23 buah..

Variabel $\mathrm{X}_{2}$ Jumlah biaya Usaha yang dikeluarkan oleh perusahaan dari sampel penelitian menunjukan bahwa sebanyak 38 buah atau $63,34 \%$ dibawah rata-rata dan yang sama dengan rata-rata sebanyak 7 buah atau $11,67 \%$ yaitu kisaran antara 325 juta rupiah sampai dengan 425 juta rupiah, sedangkan di atas rata-rata sebanyak 15 buah .

Variabel $\mathrm{X}_{3}$ Modal Kerja yang digunakan dalam perusahaan seperti pada tabel 1 tersebut menunjukan bahwa sebanyak 15 buah atau $25 \%$ sama dengan rata-rata dari sampel yaitu kisaran antara 110 juta rupiah sampai dengan 130 juta rupiah, modal kerja di bawah rata-rata sampel sebanyak 25 buah atau 41,67\%, dan sisanya sebanyak 20 buah atau $33,33 \%$.

Variabel $\mathrm{X}_{4} \quad$ Laba Usaha yang diperoleh dari hasil penjualan setelah dikurangi jumlah biaya menunjukan bahwa dari jumlah sampel penelitian sebanyak 49 buah atau $81,67 \%$ di bawah rata-rata laba menurut kisaran antara 135 juta rupiah, yanag sama dengan rata-rata sebanyak 4 buah atau $6,67 \%$, dan sebanyak 7 buah di atas rata-rata laba dari sampel penelitian.

Variabel $\mathrm{X}_{5} \quad$ Profit Margin yang diperoleh menunjukan bahwa sebanyak 3 Jumal Riset Inspizasi Manajomen dan Kowiratusabaan 
buah atau 5\% masih di bawah rata-rata, sebanyak 18 buah atau 30\% sama dengan rata-rata kisaran antara $4 \%$ sampai 5\%, dan sebanyak 39 buah dari sampel penelitian profit margin yang dicapai di atas rata-rata yaitu kisaran antara 5\% sampaai dengan $8 \%$.

Variabel $\mathrm{X}_{6}$ Jumlah Aktiva yang dimilki oleh perusahaan yang menjadi sampel penelitian menunjukan bahwa sebanyak 40 buah perusahaan memiliki aktiva di bawah rata-rata dari jumlah sampel yaitu kisaran antara 650 juta rupiah, yang sama dengan rata-rata hanya satu buah, sedangkan di atas rata-rata sebanyak 19 buah yaitu kisaran antara 740 juta rupiah sampai dengan 1280 juta rupiah.

Variabel $\mathrm{X}_{7}$ Perputaran Aktiva dari perusahaan yang menjadi sampel penelitian menunjukan bahwa sebanya 50 buah masih di bawah rata-rata tingkat perputaran aktiva yaitu 4,5 kali, yang sama dengan rata-rata sebanyak 9 buah atau $15 \%$, dan yang diatas rata-rata sebanyak satu buah perusahaan yaitu antara 6 kali sampai 7 kali tingkat perutaran.

Variabel Y Rentabilitas Ekonomi atau Earning Power yang diperoleh oleh perusahaan sampel penelitian menunjukan bahwa sebanyak 19 buah perusahaan atau $31,67 \%$ berada pada rata-rata yaitu kisaran antara $15 \%$ sampai dengan 17,50\%, sebanyak 12 buah atau $20 \%$ berada di atas Jumal Riset Inspizasi Manajemen dan Kowirausabaan 64 rata-rata yaitu antara $17,50 \%$ sampai dengan $27,50 \%$, sedangkan yang berada di bawah rata-rata sebanyak 29 buah atau $48,33 \%$ yaitu kisaran antara 7,50\% sampai dengan $15,00 \%$. 


\section{ANALISIS}

Dengan menggunakan model analisis regresi berganda, diperoleh hasil seperti pada tabel berikut ini.

Tabel

Rekapitulasi Hasil Regersi Berganda dari Variabel yang Memepengaruhi Rentabilitas pada Perusahaan Dagang di Kotamadya Banjarmasin

\begin{tabular}{|c|l|r|r|r|r|c|}
\hline No. & \multicolumn{1}{|c|}{ Variabel } & \multicolumn{1}{c|}{ Koef.Reg. } & \multicolumn{1}{c|}{ T hitung } & \multicolumn{1}{c|}{ Prob. } & $\mathrm{r}^{2}$ parsial & Ket \\
\hline 1. & $\mathrm{X}_{1}$ Penjualan Bersih & 1.4269 & 2.818 & .00552 & .2011 & $\mathrm{~S}$ \\
2. & $\mathrm{X}_{2}$ Biaya Usaha & -.0329 & -1.718 & .04850 & .0715 & $\mathrm{~S}$ \\
3. & $\mathrm{X}_{3}$ Modal Kerja & .0114 & .917 & .16351 & .0059 & $\mathrm{TS}$ \\
4. & $\mathrm{X}_{4}$ Laba Usaha & .0207 & 1.771 & .04395 & .0772 & $\mathrm{~S}$ \\
5. & $\mathrm{X}_{5}$ Profit Margin & 2.4269 & 5.188 & .00000 & .3411 & $\mathrm{~S}$ \\
6. & $\mathrm{X}_{6}$ Jumlah Aktiva & .0109 & 1.455 & .14168 & .0081 & $\mathrm{TS}$ \\
7. & $\mathrm{X}_{7}$ Perputaran Aktiva & .3779 & 1.838 & .02125 & .0986 & $\mathrm{~S}$ \\
8. & Constanta & -.0338 & & & & \\
\hline
\end{tabular}

R Square $=.6345 \quad$ F ratio $=12.897 \quad$ Multiple $\mathrm{R}=.7966 \quad$ Probabilitas $=1.778 \mathrm{E}-09$

$\mathrm{S}=$ signifikan $\mathrm{TS}=$ tidak signifikan

Dari hasil uji F didapatkan $\mathrm{F}$ ratio sebesar 12.897 lebih besar jika dibandingkan dengan $\mathrm{F}$ tabel 2,17 pada taraf nyata alpa 0,05. Hasil ini menunjukan bahwa variasi variabel bebas secara bersama-sama mempunyai pengaruh yang signifikan terhadap variasi veariabel tidak bebas yang berarti hipotesis pertama yang menyatakan bahwa faktor penjualan bersih, biaya usaha, modal kerja, laba usaha, profit margin, jumlah aktiva, dan perputaran aktiva mempunyai pengaruh yang signifikan terhadap rentabilitas pada perusahaan dagang di kotamadya Banjarmasin.

Berdasarkan nilai koefisien determinasi $\mathrm{R}$ Square 0.6345 menunjukan bahwa variabel $\begin{array}{lllll}\mathrm{X}_{1} & \text { sampai dengan } & \mathrm{X}_{7} & \text { mampu }\end{array}$ menjelaskan variabelitas rentabilitas atau keberhasilan perusahaan dagang sebesar 0,6345 atau $63,45 \%$ sedangkan sisanya 0,3655 atau $36,55 \%$ dijelaskan oleh varaiabel-variabel lain yang tidak diteliti.

Kemudian, untuk memebuktikan hipotesis kedua yaitu dengan melihat tingkat signifikan koefisien korelasi partial $\mathrm{r}^{2}$ dari masing-masing variabel bebas melalui uji $\mathrm{t}$ secara sendiri-sendiri.

Hasil uji t menunjukan bahwa t hitung dari variabel $\mathrm{X}_{1}$ sebesar 2,818 lebih besar dari $\mathrm{t}$ tabel 1,671, ini menunjukan bahwa variabel penjualan bersih mempunyai pengaruh yang signifikan terhadap tingkat rentabilitas. Variabel $\mathrm{X}_{2}$ menunjukan hasil $\mathrm{t}$ hitung sebesar $-1,718$ lebih besar dari $\mathrm{t}$ tabel 1,671, variabel ini juga mempunyai 
pengaruh yang signifikan terhadap tingkat keberhasilan(rentabilitas). Variabel $X_{3}$ menghasilkan t hitung sebesar 0,917 lebih kecil dibandingkan dengan $\mathrm{t}$ tabel 1,671, berarti variabel modal kerja tidak signifikan pengaruhnya terhadap tingkat rentabilitas. Variabel $\mathrm{X}_{4}$ menunjukan hasil t hitung sebesar 1,771 lebih besar dari t tabel 1,671 berarti variabel laba usaha mempunyai pengaruh yang signifikan terhadap rentabilitas. Variabel $\mathrm{X}_{5}$ menghasilkan t hitung sebesar 5,188 lebih besar dibandingkan dengan $\mathrm{t}$ tabel 1,671 berarti vaariabel profit margin mempunyai pengaruh signifikan terhadap rentabilitas. Variabel $\mathrm{X}_{6}$ menghasilkan t hitung 1,455 lebih kecil dibandingkan dengan $\mathrm{t}$ tabel 1,671 berarti variabel jumlah aktiva pengaruhmya tidak signifikan terhadap rentabilitas.

Variabel $\mathrm{X}_{7}$ menunjukan $\mathrm{t}$ hitung sebesar 1,838 lebih besar dibandingkan dengan $\mathrm{t}$ tabel 1,671 berarti variabel perputaran aktiva mempunyai pengaruh yang signifikan terhadap tingkat rentabilitas atau tingkat keberhasil perusahaan dagang di kotamadya Banjarmasin.

Hasil uji t dari masing-masing variabel bebas $\left(\mathrm{X}_{1}\right.$ sampai $\left.\mathrm{X}_{7}\right)$ menunjukan bahwa nilai koefisien diterminasi parsial yang tertinggi adalah $\mathrm{r}^{2}$ variabel $\mathrm{X}_{5} \quad(0,3411)$ dari koefisien diterminasi variabel lainnya. Hal ini berati bahwa variabel Profit Margin mempunyai pengaruh yang dominan terhadap tingkat rentabilitas atau keberhasilan dari perusahaan dagang di kotamadya Banjarmasin. Hipotesis kedua menyatakan bahwa faktor atau variabel penjualan bersih mempunyai pengaruh dominan terhadap rentabilitas atau tingkat berhasil pada perusahaan dagang di kotamadya Banjarmasin, dengan hasil uji t diperoleh vaariabel profit margin yang dominan, sehingga hipotesis kedua tidak terbukti atau ditolak.

\section{SIMPULAN}

Berdasarkan hasil penelitian dan analisis data dengan menggunakan uji $\mathrm{F}$ terhadap semua variabel menunjukan bahwa secara bersama-sama faktor penjualan bersih, biaya usaha, modal kerja, laba usaha, profit margin, jumlah aktiva, dan perputaran aktiva mempunyai pengaruh yang signifikan terhadap keberhasilan (rentabilitas) pada perusahaan dagang di kotamadya Banjarmasin yang ditujukan dari hasil $F$ hitung $(12,897)$ lebih besar dibandingkan dengan $\mathrm{F}$ tabel $(2,17)$, dengan demikian hipotesis pertama terbukti. Kemudian dari hasil uji t secara partial menunjukan bahwa dari tujuh faktor yang dianalisis dua dianataranya tidak mempunyai pengaruh yang signifikan terhadap tingkat rentabilitas yaitu faktor modal kerja t hitungnya 0,917 dan jumlah aktiva t hitungnya 1,455 lebih kecil dibanding dengan $\mathrm{t}$ tabel 1,671. 
Diantara faktor tersebut ternyata faktor profit magin yang mempunyai pengaruh yang dominan terhadap rentabilitas, sehingga hipotesis yang kedua tidak terbukti.

Tingkat keberhasil yang dicapai oleh perusahaan yang ditunjukan dari rentabilitas yang dicapai sebanyak 19 buah perusahaan atau $31,67 \%$ berada pada rata-rata yaitu kisaran antara 15\% sampai dengan $17,50 \%$, sebanyak 12 buah atau $20 \%$ berada di atas rata-rata yaitu antara $17,50 \%$ sampai dengan 27,50\%, sedangkan yang berada di bawah rata-rata sebanyak 29 buah atau 48,33\% yaitu kisaran antara $7,50 \%$ sampai dengan $15,00 \%$, hal ini menggambarkan bahwa perusahaan dagang dalam menjalankan usahanya mampu menghasilkan pendapatan yang selanjutnya dapat menjamin kelangsungan usaha.

\section{DAFTAR PUSTAKA}

Munawir, S., 2010, Analisa Laporan Keuangan, Cetakan kedua, Penerbit Liberty, Yogyakarta.

Mursinto, Djoko, 2000, Ekonometri Salah Satu Alat Analisis Ekonomi, FE Unair, Surabaya.

Riyanto, Bambang, 2010, Dasar-dasar Pembelanjaan Perusahaan, Edisi ke Tiga, Cetakan ke Duabelas, Yayasan Badan Penerbit Gajah Mada, Yogyakarta

Singarimbun, Masri dan Sofyan Effendi (penyunting), 2004, Metode Penelitian Survey, LP3ES, Jakarta.

Sudjana, 2003, Teknik Analisis Regresi dan Korelasi bagi para Peneliti, Edisi Pertma,Tarsito, Bandung.

Van Horne, James C., 2009, Financial Management and Policy. Eigth Edition, Prentice-Hall Inc., Englewood Cliffs, New Jersy 